\title{
A comparison of the chromosome complement of inner cell mass and trophoblast cells in Day-10 pig embryos
}

\author{
Susan E. Long and C. V. Williams \\ Department of Animal Husbandry, University of Bristol, Langford House, Langford, \\ Bristol BS18 7DU, U.K.
}

\begin{abstract}
Summary. Cytogenetic examination was made of 31 entire, Day-10 pig embryos, 39 separated inner cell masses and 38 of the related trophoblast samples. The incidence of mixoploidy was $64 \cdot 5,5 \cdot 1$ and $47.4 \%$ respectively. The incidence of triploidy was $2.9 \%$. It was concluded that polyploid cells in entire Day-10 pig embryos were primarily located in the trophoblast and that the incidence of true mixoploidy in porcine embryos is very low.
\end{abstract}

\section{Introduction}

There have been a number of reports of cytogenetic investigations of preimplantation blastocysts in a variety of species in which the incidence of polyploidy and in particular mixoploidy has been quite high although some workers have not reported such findings (Table 1). We feel that these results may reflect a difference in interpretation of material rather than a true difference in embryo populations.

The purpose of the present work was to investigate the origin of the polyploid cells in preimplantation blastocysts and to evaluate their significance in relation to the diagnosis of the karyotype of the embryo as a whole.

\section{Materials and Methods}

Seventy-one Day-10 pig embryos (PI. 1, Fig. 1) were obtained post mortem from Large White sows which had been mated once only by a boar. Thirty-one embryos were dissociated by forcing them through a 25-gauge hypodermic needle and then incubated for $3 \mathrm{~h}$ at $37^{\circ} \mathrm{C}$ in $5 \mathrm{ml}$ Minimum Essential Medium (Flow Laboratories Ltd, Scotland) with Earle's salts supplemented with $10 \%$ fetal calf serum, $1 \% \mathrm{~L}$-glutamine, $1 \%$ antibiotics (stock: 10000 i.u. penicillin $+10000 \mu \mathrm{g}$ streptomycin) and $7.5 \mu \mathrm{g}$ colcemid $/ \mathrm{ml}$. One entire, undissociated embryo was placed directly into $0.8 \%$ sodium citrate at $37^{\circ} \mathrm{C}$ for $10 \mathrm{~min}$ without prior incubation. It was then fixed whole onto a slide using methanol :acetic acid fixative $(3: 1, \mathrm{v} / \mathrm{v})$. In a further 39 embryos the inner cell mass was dissected from the trophoblast cells. The inner cell mass and trophoblast were then cultured separately without dissociation. Culture time and medium were as described above.

To harvest, the dissociated embryos were treated with $0.8 \%$ sodium citrate solution and methanol : acetic acid fixative $(3: 1, \mathrm{v} / \mathrm{v})$ solution as for standard fibroblast cultures (Hyman \& Poulding, 1972). The isolated inner cell mass and trophoblast samples were removed whole from the culture medium and placed in $0.8 \%$ sodium citrate solution at $37^{\circ} \mathrm{C}$ for approximately $10 \mathrm{~min}$. Each sample was then placed on a slide and a few drops of methanol : acetic acid fixative $(1: 1, \mathrm{v} / \mathrm{v})$ at $0^{\circ} \mathrm{C}$ were dropped on to it. The sample was then mechanically dissociated with the tip of a glass pipette. 
Table 1. Cytogenic examination of expanded preimplantation blastocysts

\begin{tabular}{|c|c|c|c|c|}
\hline \multirow[b]{2}{*}{ Species } & \multirow[b]{2}{*}{ Reference } & \multicolumn{3}{|c|}{ Chromosome complement, no. $(\%)$} \\
\hline & & $2 n$ & Polyploid & Mixoploid \\
\hline Rabbit* & $\begin{array}{l}\text { Shaver \& Carr, } 1967 \\
\text { Martin \& Shaver, } 1972 \\
\text { Widmeyer \& Shaver, } 1972 \\
\text { Stranzinger \& Lodge, } 1974 \\
\text { Fujimoto, Pahlavan \& Dukelow, } 1974\end{array}$ & $\begin{array}{r}42(89 \cdot 4) \\
104(99 \cdot 0) \\
71(98 \cdot 6) \\
27(75 \cdot 0) \\
46(100)\end{array}$ & $\begin{array}{c}0 \\
0 \\
0 \\
1(2 \cdot 8) \\
0\end{array}$ & $\begin{array}{l}3(6.4) \\
1(0.95) \\
0 \\
3(13.9) \\
0\end{array}$ \\
\hline Pig & $\begin{array}{l}\text { McFeely, } 1967 \\
\text { Moon, Rashad \& Mi, } 1975 \\
\text { Dolch \& Chrisman, } 1981\end{array}$ & $\begin{array}{l}77(87 \cdot 5) \\
11(73) \\
169(100)\end{array}$ & $\begin{array}{l}7(8 \cdot 0) \\
1(6 \cdot 7) \\
0\end{array}$ & $\begin{array}{c}1(1 \cdot 1) \\
2(20 \cdot 0) \\
0\end{array}$ \\
\hline Cattle & $\begin{array}{l}\text { McFeely \& Rajakoski, } 1968 \\
\text { Hare et al., } 1980 \\
\text { Popescu, } 1980 \dagger\end{array}$ & $\begin{array}{l}11(91 \cdot 7) \\
90(56 \cdot 6) \\
61(96 \cdot 8)\end{array}$ & $\begin{array}{c}0 \\
1(0 \cdot 63) \\
0\end{array}$ & $\begin{array}{c}1(8 \cdot 3) \\
68(42 \cdot 8) \\
0\end{array}$ \\
\hline Sheep & Long, $1977 \dagger$ & $75(100)$ & 0 & 0 \\
\hline
\end{tabular}

* Data from control animals only.

† Balanced translocation carriers grouped with $2 \mathrm{n}$ embryos.

All the slides were stained with $10 \%$ Giemsa (Gurr R66) at pH 6.8 for 10 min and permanent mounts were made. The whole, undissociated embryo was examined for the presence of binucleate or giant cells. The dissociated embryos, inner cell mass and trophoblast samples were examined for metaphase spreads. All countable spreads were recorded and no judgement was made as to whether the chromosome groups came from one or more cells.

\section{Results}

There was considerable variation in the size of the embryos (range: 4-10 mm diameter) but all were round blastocysts and none had an elongated, expanded trophoblast. The undissociated uncultured embryo clearly showed two different cell types in the trophoblast (PI. 1, Fig. 2). The majority of cells had small, darkly stained nuclei but some were much larger and stained more palely.

The results of the cytogenetic screening of the material are shown in Table 2. Mitotic index was generally much higher in isolated inner cell masses compared to trophoblast samples or dissociated entire embryos (Pl. 2, Figs 3 and 4). In the entire embryos $64.5 \%$ showed some degree of mixoploidy compared to $47.4 \%$ of the trophoblast samples. This was not a statistically significant difference. Only $5 \cdot 1 \%$ of the inner cell mass samples showed mixoploidy, a value significantly different from that for entire embryos $\left(\chi^{2}=12.6 ; P<0.001\right)$ and trophoblast cells $\left(\chi^{2}=8.76 ; P<0.01\right)$. Two of the inner cell masses had cells with a triploid chromosome complement and one of these was paired with a trophoblast with cells of $3 n$ and $6 n$. Metaphase spreads from the corresponding trophoblast of the second inner cell mass were of poor quality and a definite diagnosis could not be made.

Table 2. Cytogenic examination of Day-10 pig embryos

\begin{tabular}{lccccccc}
\hline & \multicolumn{6}{c}{ Chromosome complement, no. (\%) } \\
\cline { 2 - 6 } & Diploid & Polyploid & \multicolumn{4}{c}{ Mixoploid } \\
\cline { 5 - 7 } & $2 \mathrm{n}$ & $3 \mathrm{n}$ & $2 \mathrm{n} / 4 \mathrm{n}$ & $2 \mathrm{n} / 3 \mathrm{n} / 4 \mathrm{n}$ & $2 \mathrm{n} / 4 \mathrm{n} / 8 \mathrm{n}$ & $3 \mathrm{n} / 6 \mathrm{n}$ & Total \\
\hline Entire embryo & $11(35 \cdot 5)$ & - & $13(41 \cdot 9)$ & $1(3 \cdot 2)$ & $6(19 \cdot 4)$ & - & 31 \\
Trophoblast & $20(55 \cdot 5)$ & - & $13(36 \cdot 1)$ & - & $4(11 \cdot 1)$ & $1(2 \cdot 8)$ & 38 \\
Inner cell mass & $35(89 \cdot 7)$ & $2(5 \cdot 1)$ & $2(5 \cdot 1)$ & - & - & - & 39 \\
\hline
\end{tabular}



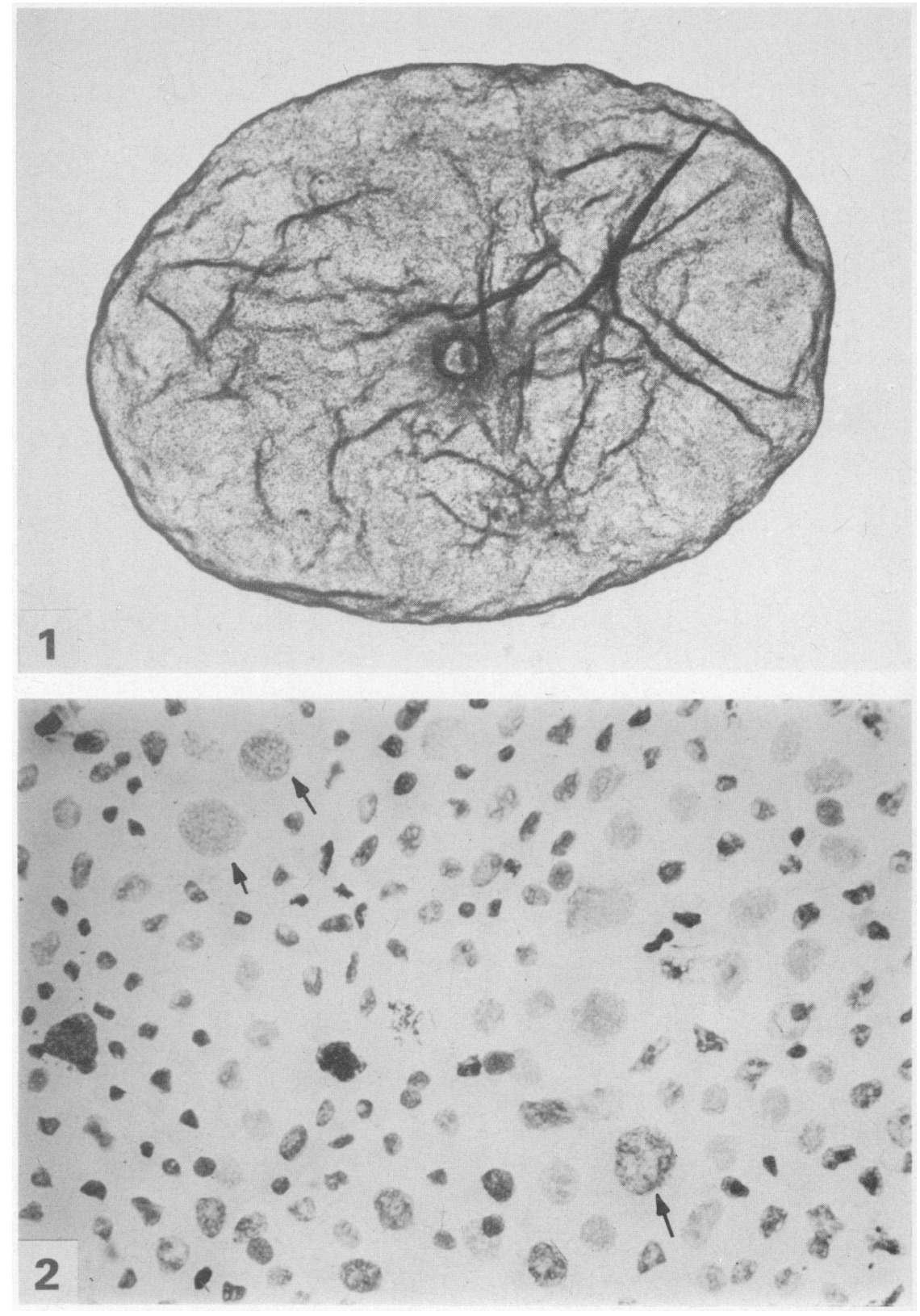

Fig. 1. A Day-10 pig embryo showing the clearly delineated inner cell mass in the centre of the blastocyst. $\times 10$.

Fig. 2. A portion of trophoblast from a Day-10 pig embryo which was fixed without prior incubation. The large, pale staining nuclei (arrowed) of the giant cells contrast with the smaller, darkly staining nuclei of the other trophoblast cells. H \& E, $\times 32$. 


\section{PLATE 2}

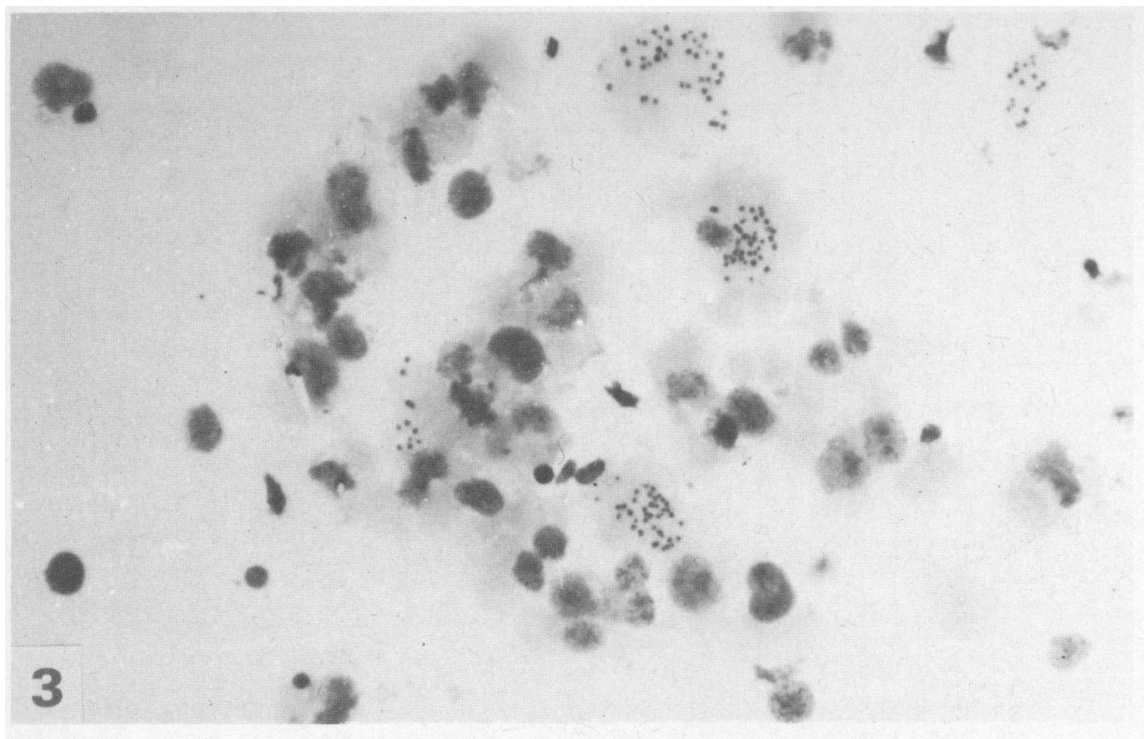

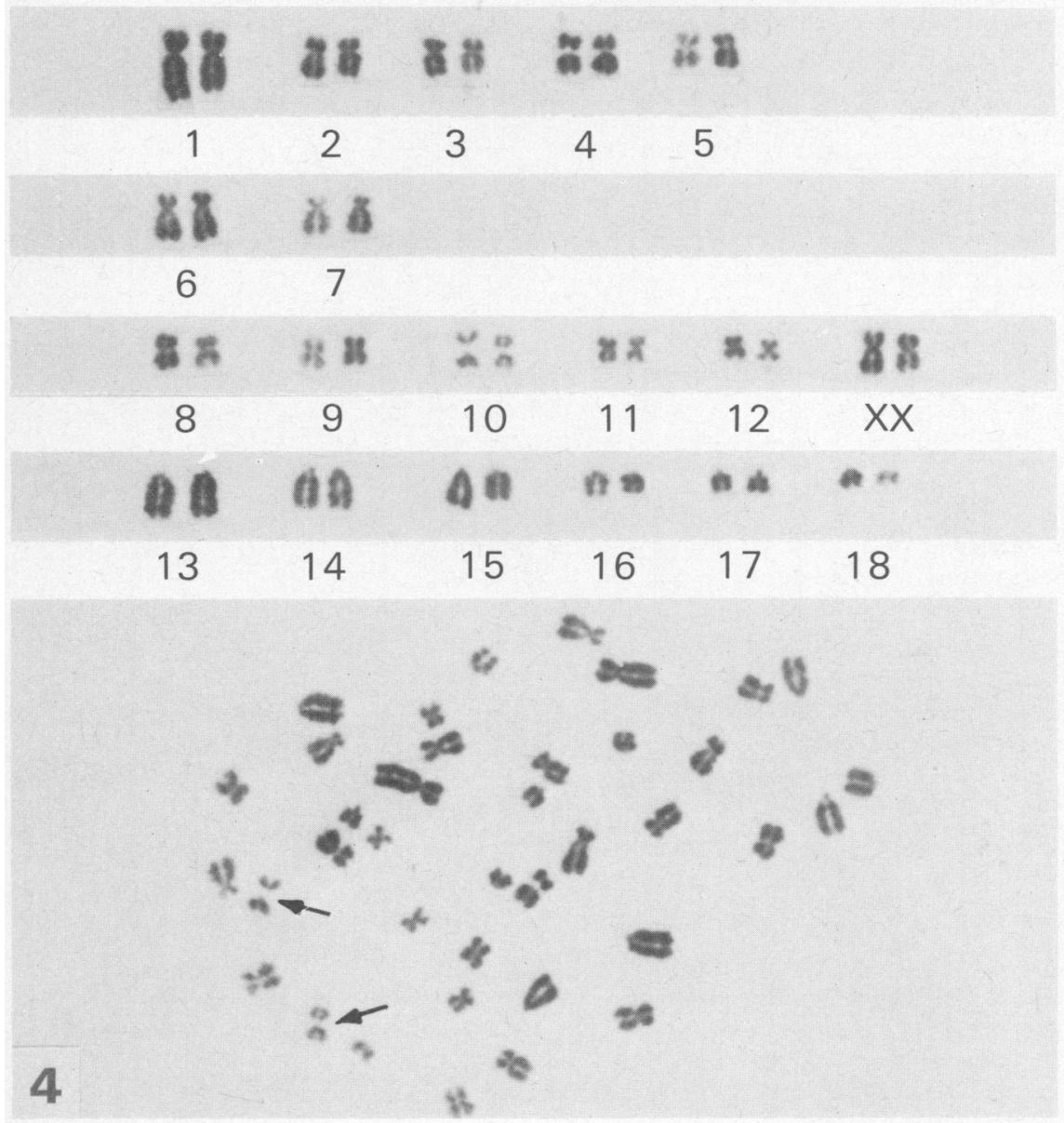




\section{Discussion}

The results indicate that the polyploid cells in Day-10 pig embryos are primarily located in the trophoblast. This conflicts with an earlier report for the rabbit (Venge, 1956) in which no significant difference was found between the chromosome complement of the inner cell mass and trophoblast of 6-day embryos. However, Venge (1956) was using the squash technique for chromosome examination and this method can make interpretation of results difficult. It has been suggested that polyploid cells in preparations from preimplantation embryos originate from binucleate and giant cells in the trophoblast (Long \& Williams, 1980; Hare et al., 1980). This hypothesis is supported by the finding of binucleated and presumptive giant cells in trophoblast material in the present work. Binucleate cells are known to be present in sheep trophoblast by Day 16 (Boshier, 1969) and cow trophoblast by Day 15 (Staples, McEntee \& Hansel, 1961) and this is the time at which most investigations of preimplantation embryos are made.

In the mouse, extensive studies on the relationship between cell division in the inner cell mass and trophoblast have shown that the ploidy of trophoblast cells rises progressively throughout gestation (Barlow \& Sherman, 1972). This is achieved by endoreduplication of trophectoderm cells most distant from the inner cell mass (Rossant \& Tamura-Lis, 1981). This phenomenon has important implications if the same effect occurs in cattle, since embryo sexing and chromosome analysis at the 14-day stage are carried out after trophoblast biopsy (Hare, Mitchell, Betteridge, Eaglesome \& Randall, 1976). Indeed, in one report, 39.7\% of 12-15-day cattle embryos analysed by this method had polyploid cells (Hare et al., 1980). The incidence of polyploid cells ranged from $0 \%$ in Day- 12 embryos to $9.9 \%$ in Day- 15 embryos.

Not all polyploid cells can be attributed to trophoblast cells. In the present work two triploid embryos were identified. This was an incidence of $2.9 \%(2 / 70)$ which compares with $4.6 \%(4 / 88)$ reported by McFeely (1967). In bovine embryos at a similar developmental stage the incidence of triploidy has been reported to be $0.63 \%(1 / 59)$ (Hare et al., 1980). No triploid embryos were found in the 75 preimplantation sheep embryos examined by Long (1977).

We thank Dr M. J. Manners for help with the experimental material. C.V.W. was supported by a grant from the Agricultural Research Council.

\section{References}

Barlow, P.W. \& Sherman, M.I. (1972) The biochemistry of differentiation of mouse trophoblast; studies on polyploidy. J. Embryol. exp. Morph. 27, 447-465.

Boshier, D.P. (1969) A histological and histochemical examination of implantation and early placentome formation in sheep. J. Reprod. Fert. 19, 51-61.

Dolch, K.M. \& Chrisman, C.L. (1981) Cytogenetic analysis of preimplantation blastocysts from prepuberal gilts treated with gonadotropins. Am. J. vet. Res. 42, 344-346.

Fujimoto, S., Pahlavan, N. \& Dukelow, W.R. (1974) Chromosome abnormalities in rabbit preimplantation blastocysts induced by superovulation. $J$. Reprod. Fert. 40, 177-181.
Hare, W.C.D., Mitchell, D., Betteridge, K.J., Eaglesome, M.D. \& Randall, G.C.B. (1976) Sexing two-week-old bovine embryos by chromosomal analysis prior to surgical transfer; preliminary methods and results. Theriogenology 5, 243-253.

Hare, W.C.D., Singh, E.L., Betteridge, K.J., Eaglesome, M.D., Randall, G.C.B., Mitchell, D., Bilton, R.J. \& Trounson, A.O. (1980) Chromosomal analysis of 159 bovine embryos collected 12 to 18 days after oestrus. Can. J. Genet. Cytol. 22, 615-626.

Hyman, J.M. \& Poulding, R.H. (1972) Culture and preparation of human fibroblasts for chromosome studies. In Animal Tissue Culture, pp. 147-165. Ed. G. D. Wasley. Butterworths, London.

\section{PLATE 2}

Fig. 3. Cells from an isolated inner cell mass of a Day-10 pig embryo after culture showing individual, well separated diploid metaphase spreads. Giemsa, $\times 160$.

Fig. 4. Karyotype and spread of a cell from the inner cell mass, $2 n=38 X X$. The secondary constriction on chromosome 10 (arrowed) makes it easily recognizable in the spread. 
Long, S.E. (1977) Cytogenetic examination of preimplantation blastocysts of ewes mated to rams heterozygous for the Massey I $\left(t_{1}\right)$ translocation. Cytogenet. Cell Genet. 18, 82-89.

Long, S.E. \& Williams, C.V. (1980) Frequency of chromosomal abnormalities in early embryos of the domestic sheep (Ovis aries). J. Reprod. Fert. 58, 197201.

Martin, P.A. \& Shaver, E.L. (1972) Sperm ageing in utero and chromosomal anomalies in rabbit blastocysts. Devl Biol. 28, 480-486.

McFeely, R.A. (1967) Chromosome abnormalities in early embryos of the pig. J. Reprod. Fert. 13, 579-581.

McFeely, R.A. \& Rajakoski, E. (1968) Chromosome studies on early embryos of the cow. Proc. 6th Int. Congr. Anim. Reprod. \& A. I., Paris 2, 905-907.

Moon, R.G., Rashad, M.N. \& Mi, M.P. (1975) An example of polyploidy in pig blastocysts. J. Reprod. Fert. 45, 147-149.

Popescu, C.P. (1980) Cytogenetic study on embryos sired by a bull carrier of $1 / 29$ translocation. Proc. 4 th Eur. Colloq. Cytogenet. Domestic Anim. pp. 182-186.
Rossant, J. \& Tamura-Lis, W. (1981) Effect of culture conditions on diploid to giant cell transformation in post implantation mouse trophoblast. J. Embryol. exp. Morph. 62, 217-227.

Shaver, E.L. \& Carr, D.H. (1967) Chromosome abnormalities in rabbit blastocysts following delayed fertilisation. J. Reprod. Fert. 14, 415-420.

Staples, R.E., McEntee, K. \& Hansel, W. (1961) Luteal function as related to pituitary and ovarian cytology and embryo development in the bovine. J. Dairy Sci. 44, 2049-2057.

Stranzinger, G.F. \& Lodge, J.R. (1974) Sperm ageing effects on the chromosomal complement in rabbit blastocysts. Z. Tierzücht. ZüchtBiol. 91, 125-130.

Venge, O. (1956) Chromosome number in rabbit blastocysts. Nature, Lond. 177, 384-385.

Widmeyer, M.A. \& Shaver, E.L. (1972) Estrogen, progesterone and chromosome abnormalities in rabbit blastocysts. Teratology 6, 207-214.

Received 15 March 1982 